\title{
REASONS FOR CRACKING OF DIE-FORGED CuZn34Mn3AI2FeNi BRASS BLANKS
}

\author{
N. B. Pugacheva*, Yu. V. Khudorozhkova, E. B. Trushina, \\ A. V. Gerasimova, N. P. Antenorova \\ Institute of Engineering Science, Ural Branch of the Russian Academy of Sciences, \\ 34 Komsomolskaya St., Ekaterinburg, 620049, Russian Federation \\ *Corresponding author. E-mail: nat@imach.uran.ru \\ Address for correspondence: 34 Komsomolskaya St., Ekaterinburg, 620049, Russian Federation \\ Tel.: 83433753591
}

The structural state of annular work pieces made of brass CuZn34Mn3Al2FeNi after hot forming at temperatures of 700 and $780{ }^{\circ} \mathrm{C}$ is studied. Electron microprobe analysis of the material of rings shows the absence of any harmful impurities, low melting eutectics, silicides and nonmetallic inclusions on the $\beta$ '-grain interfaces. Irregularity of the dynamic recrystallization process in the cross section of the rings has been revealed; namely, there are two zones differing in the amount of deformation. One area with minimal deformation and excessively large grain, the second - with the maximum deformation and small grain resulting from dynamic recrystallization. Determined that heating for stamping to 780 Cresults togrowth of $\beta$ '-grains up to $0.3 \mathrm{mmin}$ the area with mini-

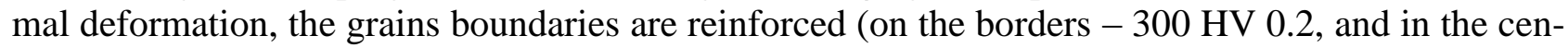


action of internal residual stresses formed during cooling of blanks. Lowering the temperature of heating for forging to $700 \mathrm{C}$ reduces the size of the maximum $\beta^{\prime}$-grains up to $0.15 \mathrm{~mm}$, thus not detected hardening of their borders that helps to preserve the integrity of the rings after cooling.

Keywords: brass, deformation, microstructure, fracture, crack, dynamic recrystallization, residual stresses, hardness

DOI: $10.17804 / 2410-9908.2017 .4 .061-080$

\section{References}

1. Suchkov D.I. Med i Ee Splavy [Copper and its Alloys]. M., Metallurgy Publ., 1967, 248 p. (In Russian).

2. Turkin V.D. Rumyantsev M.V. Struktura i Svoistva Tsvetnykh Metallov $i$ Splavov [Structure and Properties of Nonferrous Metals and Alloys]. Moscow, Metallurgizdat Publ., 1944, 440 p. (In Russian).

3. Efremov B.N. Latuni. Ot Fazovogo Stroeniya $k$ Structure i Svoistvam [Brasses. From Phase Texture to the Structure and Properties: monograph]. Moscow, INFRA-M Publ., 2014, 312 p. (In Russian).

4. Elagin V.A., Kolachev A.V., Livanov V.A. Metallovedenie i Termicheskaya Obrabotka Tsvetnykh Metallov $i$ Splavov [Metal Science and Heat Treatment of Nonferrous Metals and Alloys]. Moscow, MISIS Publ., 2005, 432 p. (In Russian).

5. Krasnenkov V.I., Egorkin V.V. Sinkhronizatory v Stupenchatykh Transmissiyakh [Synchronizers in Stepped Transmission]. Moscow, Mashinostroenie Publ., 1967, 195 p. (In Russian).

6. Pugacheva N.B. Struktura i Svoistva Deformiruemykh Legirovannykh Latuney [Structure and Properties of Deformed Alloy Brasses]. Ekateriburg, UrORAN Publ., 2012, 172 p. (In Russian).

7. Tropotov A.V. Pugacheva N.B., Ryazantsev Yu.V., Zhukova L.M. A study of residual stresses in products made of hard alloy of brass. Metal Science and Heat Treatment, 2006, vol. 47, nos. 1-2, pp. 31-35. DOI: 10.1007/s11041-006-0039-5 
8. Kopyl M.D., Kropotov A.V., Kotlyarov I.V. Improving brass alloys for synchronizer rings. Avtomobilnaya Promyshlennost, 1999, no. 10, pp. 26-29. (In Russian).

9. Smirnov S.V., Pugacheva N.B., Soloshenko A.N., Tropotov A.V. Plastic deformation of a high-alloy brass. Physics of Metals and Metallography, 2002, vol. 93, no. 6, pp. 584-593.

10. Cai W., Liu H.F., Hu Z.Q. Effect of Ni on structure and characteristics of Cu-Zn Brass to 22.7 As-cast. Advanced Materials Research, 2012, vol. 581-582, no. 1, pp. 556-560.

11. RD 50-672-88: Calculations and strength tests, classification of fractures of metals: methodical instructions, Moscow, Izd-vo Standartov Publ., 1989, 21 p.

12. Shimov G.V., Kovin D.S. Residual stresses in copper and brass tubes after drawing. Izvestiya VUZov: tsvetnaya metallurgiya, 2015, special issue, pp. 46-49. (In Russian).

13. Pugacheva N.B., Trushina E.B., Antenorova N.P., Ovchinnikov A.S., Lebed A.V. Studying the nature and reasons for the fracture of extruded $58 \mathrm{Cu}-34 \mathrm{Zn}-3 \mathrm{Mn}-2 \mathrm{Al}$ alloy billets. Voprosy Materialovedeniya, 2014, no. 1 (77), pp. 56-64. (In Russian).

14. Gorelik S.S. Dobatkin S.V., Kaputkina L.M. Rekristallizatsiya Metallov i Splavov [Recrystallization of Metals and Alloys]. Moscow, Izd-vo MISIS Publ., 2005, 432 p. (In Russian).

15. Grachev S.V., Baraz V.R., Bogatov V.P., Shveykin V.P. Fizicheskoe Materialovedenie [Physical Materials Science: Textbook for High Schools, 2nd ed., S.V. Grachev, ed.]. Ekaterinburg, Izd-vo UPI Publ., 2009, 548 p.]. (In Russian).

16. Tropotov A.V., Smirnov S.V., Kuznetsov V.Yu. Predicting the reliability of the forming of a "blocking synchronizer ring" part for cars. Metalloobrabotka, 2004, no. 3 (21), pp. 19-21. (In Russian).

17. Schwartz A.J. Kumar V., Adams B.L., Field D.P. Electron Backscatter Diffraction in Materials Science, Springer, Boston, MA, 2000, 395 p. DOI: 10.1007/978-0-387-88136-2

18. Varyukhin V.N., Pashinskaya E.G., Savdoveev A.V., Burkhovetsky V.V. Vozmozhnosti Metoda Difraktsii Obratnorasseyannykh Elektronov dlya Analiza Struktury Deformirovannykh Materialov [Applicability of the Electron Backscatter Diffraction Method to the Analysis of the Structure of Deformed Materials]. Kiev, Naukova Dumka, 2014, 102 p. (In Russian). 
Подана в журнал: 04.08.2017

УДК 620.18.186

DOI: $10.17804 / 2410-9908.2017 .4 .061-080$

\title{
ПРИЧИНЫ РАСТРЕСКИВАНИЯ ШТАМПОВАННЫХ ЗАГОТОВОК ИЗ ЛАТУНИ ЛМцАЖН
}

\author{
Н. Б. Пугачева ${ }^{*}$ Ю. В. Худорожкова, Е. Б. Трушина,
}

А. В. Герасимова, Н. П. Антенорова

\begin{abstract}
Федеральное государственное бюджетное учреждение науки Институт машиноведения Уральского отделения Российской академии наук, Екатеринбург, Российская Федераиия

*Ответственный автор. Электронная почта: nat@imach.uran.ru

Адрес для переписки: 620049, Екатеринбург, ул. Комсомольская, 34, Российская Федерация Тел.: +7 (343) 375-35-96; факс: +7 (343) 374-53-30
\end{abstract}

Исследовано структурное состояние кольцевых заготовок из латуни ЛМцАЖН после горячей штамповки при температурах 700 и $780{ }^{\circ} \mathrm{C}$. Микрорентгеноспектральный анализ материала колец показал отсутствие по границам $\beta^{\prime}$-зерен каких-либо вредных примесей, легкоплавких эвтектик, силицидов и неметаллических включений. Установлена неравномерность протекания динамической рекристаллизации по сечению колец: выделено две зоны, отличающиеся степенью деформации. Одна зона с минимальной деформацией и чрезмерно крупным зерном, вторая - с максимальной деформацией и мелким зерном, образовавшимся в результате динамической рекристаллизации. Определено, что при нагреве под штамповку до $780{ }^{\circ} \mathrm{C}$ в зоне с минимальной деформацией происходит рост $\beta$-зерен до 0,3 мм, границы которых упрочнены (по границам - $300 \mathrm{HV}$ 0,2, в центре зерна - $170 \mathrm{HV}$ $0,2)$, что облегчает появление и быстрый рост трещин под действием внутренних остаточных напряжений, формирующихся при охлаждении заготовок. Снижение температуры нагрева под штамповку до $700{ }^{\circ} \mathrm{C}$ приводит к уменьшению размера максимального $\beta$ '-зерна до 0,15 мм, при этом не обнаружено упрочнения границ, что способствует сохранению целостности колец при охлаждении.

Ключевые слова: латунь, деформация, микроструктура, трещина, излом, динамическая рекристаллизачия, остаточные напряжения, твердость.

\section{1. Введение}

В настоящее время в автомобилестроении широко применяются сложнолегированные латуни, которые благодаря присутствию в них легирующих элементов обладают уникальным сочетанием высокой пластичности с высокой твердостью, износостойкостью и прочностью при эксплуатации [1-5]. Из всего многообразия легированных латуней латунь марки ЛМцАЖН 59-3,5-2,5-0,5-0,4 (далее по тексту ЛМцАЖН) является практически однофазной $\beta$-латунью, существенным недостатком которой является склонность к растрескиванию под действием остаточных напряжений, возникающих после горячего деформирования [6, 7]. Действительно, при штамповке колец синхронизатора коробки передач легковых автомобилей в условиях ОАО «АВТОВАЗ» довольно часто происходит растрескивание кольцевых заготовок $[7,8]$. В работах Б.Н. Ефремова, Е.В. Юшина, И.И. Курбаткина, И.Ф. Пружинина, Н.Я. Титарева, А.В. Бобылева, С.В. Смирнова, Н.Б. Пугачевой, А.С. Овчинникова и др. показано, что главную роль в формировании прочности и стойкости к растрескиванию играет сбалансированное соотношение структурных составляющих в легированных латунях. Именно поэтому в последние годы большое значение придается изучению механизмов разрушения и влияния различных структурных и технологических факторов на характеристики разрушения заготовок и деталей из легированных латуней $[6,9,10]$. 
Цель работы заключается в определении причин растрескивания кольцевых заготовок из латуни ЛМцАЖН после горячей штамповки и определение технологических условий устранения этого дефекта.

\section{2. Материалы и основные методы исследований}

Материалом для проведения исследования послужили партии заготовок блокирующих колец синхронизатора из латуни марки ЛМцАЖН, изготовленных на Ревдинском заводе по обработке цветных металлов. Химический состав исследованной латуни по требованиям ТУ 184550-106-033-97 представлен в табл. 1.

Таблица 1 - Химический состав исследуемой латуни

\begin{tabular}{|c|c|c|c|c|c|c|c|c|c|c|c|c|c|}
\hline \multirow{2}{*}{ Марка } & \multicolumn{8}{|c|}{ Основные компоненты, \% } & \multicolumn{5}{|c|}{ Примеси (не более), \% } \\
\hline & $\mathrm{Cu}$ & $\mathrm{Mn}$ & $\mathrm{Al}$ & $\mathrm{Fe}$ & $\mathrm{Ni}$ & $\mathrm{Si}$ & $\mathrm{Pb}$ & $\mathrm{Zn}$ & $\mathrm{Si}$ & $\mathrm{Sn}$ & $\mathrm{Pb}$ & $\mathrm{Ni}$ & Всего \\
\hline  & $\begin{array}{l}n \\
8 \\
0 \\
n \\
\infty \\
n \\
n\end{array}$ & $\begin{array}{l}0 \\
\dot{I} \\
0 \\
\dot{r}\end{array}$ & $\begin{array}{l}0 \\
j \\
0 \\
i\end{array}$ & $\begin{array}{l}\hat{0} \\
\hat{0} \\
0\end{array}$ & $\begin{array}{l}n \\
\hat{1} \\
\tilde{o} \\
0\end{array}$ & 1 & 1 & $\dot{\overrightarrow{0}}$ & $\frac{n}{0}$ & $\tilde{\sigma}$ & $\frac{n}{0}$ & 1 & $n$ \\
\hline
\end{tabular}

Технология и оборудование для изготовления колец синхронизатора были первоначально приобретены у автомобильного концерна «Фиат», Италия. Как следствие, в документации ОАО «АВТОВАЗ» изначально предусматривалось использование импортного материала - легированной латуни Biak-3. В соответствии с действующей на OAO «АВТОВАЗ» практикой, сплав прошел процедуру импортозамещения, т. е. был разработан сплавзаменитель с учетом технологических особенностей предприятия. Из прессованных трубных заготовок, производимых Ревдинским заводом ОЦМ, на ОАО «АВТОВАЗ» изготавливают блокирующие кольца синхронизатора коробки перемены передачи. Технология их получения включает следующие основные операции: порезка трубы на кольца-заготовки; галтовка; обточка; штамповка колец; естественное старение в течение 3-8 сут.; обрубка облоя; стопроцентная ручная разбраковка (на прозвон); черновая механическая обработка; стабилизирующий отжиг при $370{ }^{\circ} \mathrm{C}$; чистовая механическая обработка; сдача ОТК. Только после отжига опасность растрескивания колец полностью устраняется, а до этой операции из-за высоких остаточных напряжений, формирующихся после горячей штамповки, существует опасность появления трещин.

Были исследованы 5 колец, отштампованных по разным режимам (табл. 2). Химический состав материала исследованных колец, выполненный на анализаторе SPEKTROMAXx, соответствует требованиям ТУ и приведен в табл. 3.

Для выявления микроструктуры образцы подвергались травлению реактивом: 2 г $\mathrm{K}_{2} \mathrm{CrO}_{7}+8$ г $\mathrm{H}_{2} \mathrm{SO}_{4}+4$ мл $\mathrm{NaCl}$ (насыщенный раствор) +100 мл $\mathrm{H}_{2} \mathrm{O}$. Травление проводилось путем нанесения раствора на поверхность шлифа. Время травления составляло $4 \div 5$ с. Затем образец промывался водой и высушивался в потоке теплого воздуха. Исследование микроструктуры латуни проводили с помощью оптического металлографического микроскопа NEОРНОТ-21 (увеличение от 50 до 1000 крат). Количественную оценку структурных составляющих сплава выполняли с помощью программного комплекса (ПК) Materials Workstation прибора LEICA VMHT AUTO и SIAMS 700. На приборе LEICA были выполнены замеры микротвердости по сечению $\beta^{\prime}$-зерен при нагрузке 200 г. 
Характер разрушения заготовок колец синхронизатора устанавливали в соответствие с требованиями стандарта РД 50-672-88 [11] путем выполнения макрофрактографических исследований поверхности трещин на бинокулярном микроскопе МБС-10 без увеличения и при увеличении 2 крат, а также микрофрактографических исследований на растровом электронном микроскопе TESCAN VEGA II XMU (Чехия), оснащенном системами рентгеновского волнодисперсионного микроанализа INCA WAVE 700, энергодисперсионного микроанализа INCA ENERGY 450 с ADD детектором фирмы OXFORD (Великобритания) и программным обеспечением INCA. Погрешность определения содержания химического элемента составляет не более 5 \% от измеряемой величины. Структурное состояние материала кольцевых заготовок исследовано методом анализа картин дифракции обратно-отраженных электронов (EBSD) при помощи приставки Oxford NKLNordlysF+ с программным комплекcom HKL Channel 5.

Таблица 2 - Температура нагрева перед горячей штамповкой и характеристика состояния исследованных заготовок колец

\begin{tabular}{|c|c|l|}
\hline $\begin{array}{c}\text { № } \\
\text { заготовок } \\
\text { колец }\end{array}$ & $\begin{array}{c}\text { Температура } \\
\text { штамповки, }{ }^{\circ} \mathrm{C}\end{array}$ & \multicolumn{1}{c|}{ Наличие трещин } \\
\hline 1 & 780 & Трещина на всю высоту кольца посередине канавки зуба \\
\hline 2 & 780 & $\begin{array}{l}\text { Забраковано по результатам «прозвона», при вырезке фраг- } \\
\text { мента образовалась трещина на всю высоту на противополож- } \\
\text { ной от места приложения нагрузки стороне кольца }\end{array}$ \\
\hline 3 & 780 & $\begin{array}{l}\text { Кольцо прошло операцию «прозвона», было сломано путем } \\
\text { изгиба }\end{array}$ \\
\hline 4 & 700 & $\begin{array}{l}\text { Кольцо не прошло операцию «прозвона», но трещин в процес- } \\
\text { се вырезки образцов не появилось, сломано путем изгиба }\end{array}$ \\
\hline 5 & 700 & $\begin{array}{l}\text { Кольцо прошло операцию «прозвона», было сломано путем } \\
\text { изгиба }\end{array}$ \\
\hline
\end{tabular}

Таблица 3 - Химический состав материала исследуемых колец

\begin{tabular}{|c|c|c|c|c|c|c|c|c|c|c|c|c|}
\hline \multirow{2}{*}{$\begin{array}{c}\text { № } \\
\text { коль- } \\
\text { ца }\end{array}$} & \multicolumn{12}{|c|}{ Содержание, \% } \\
\hline & $\mathrm{Zn}$ & Mn & $\mathrm{Al}$ & $\mathrm{Fe}$ & $\mathrm{Ni}$ & $\mathrm{Si}$ & $\mathrm{Pb}$ & $\mathrm{Sb}$ & $\mathrm{Cr}$ & Sn & As & $\mathrm{Cu}$ \\
\hline 1 & 35,24 & 3,02 & 2,25 & 0,491 & 0,407 & 0,153 & 0,0160 & 0,044 & 0,031 & 0,041 & 0,026 & \multirow{5}{*}{$\begin{array}{l}0 \\
0 \\
\text { A } \\
\text { 苟 } \\
0 \\
0\end{array}$} \\
\hline 2 & 34,32 & 3,07 & 2,29 & 0,499 & 0,417 & 0,154 & 0,159 & 0,041 & 0,031 & 0,040 & 0,025 & \\
\hline 3 & 35,31 & 2,92 & 2,24 & 0,491 & 0,412 & 0,146 & 0,158 & 0,042 & 0,030 & 0,039 & 0,026 & \\
\hline 4 & 34,03 & 3,02 & 2,28 & 0,510 & 0,429 & 0,151 & 0,166 & 0,042 & 0,031 & 0,040 & 0,026 & \\
\hline 5 & 34,11 & 2,99 & 2,34 & 0,510 & 0,423 & 0,154 & 0,164 & 0,043 & 0,031 & 0,040 & 0,026 & \\
\hline
\end{tabular}

Твердость латуни определяли методом Роквелла по ГОСТ 9013-59 по шкале В на твердомере ТР 5006. Индентор - металлический шар диметром 1,588 мм, нагрузка $980 \mathrm{H}$. Измерение микротвердости по сечению $\beta^{\prime}-$ зерен проводили на приборе Leica при нагрузке 200 г. по ГОСТ 9450-76 и 6507-1-2007.

\section{3. Результаты и их обсуждение}

Анализ литературных данных позволяет выделить следующие причины растрескивания кольцевых заготовок после горячей штамповки $[6-8,12]: 1)$ наличие дефектов сплошности в трубных заготовках; 2) неметаллические включения (оксиды, сульфиды), завышенное количество силицидов, примеси по границам $\beta^{\prime}$-зерен; 3) завышенные температуры нагрева 
ittp.///ream-journal.or"]

под штамповку колец, приводящие к интенсивному росту $\beta$-зерен в процессе рекристаллизации, и окислению границ зерен (пережогу); 5) формирование высоких растягивающих напряжений в кольце.

На ОАО «Р3 ОЦМ» осуществляется сплошной контроль трубных заготовок вихретоковым методом, что гарантирует отсутствие дефектов нарушения сплошности, т. е. исключение первой причины растрескивания. Что касается второй группы причин растрескивания, выполненные исследования характера распределения элементов по сечению $\beta^{\prime}$-зерен в трубных заготовках из латуни ЛМцАЖН методом микрорентгеноспектрального анализа показали, что значимых изменений химического состава по границам зерен не обнаружено (рис. 1, табл. 4). На некоторых участках поверхности обнаружено расположение частиц свинца по границам зерен (рис. 2, табл. 5).

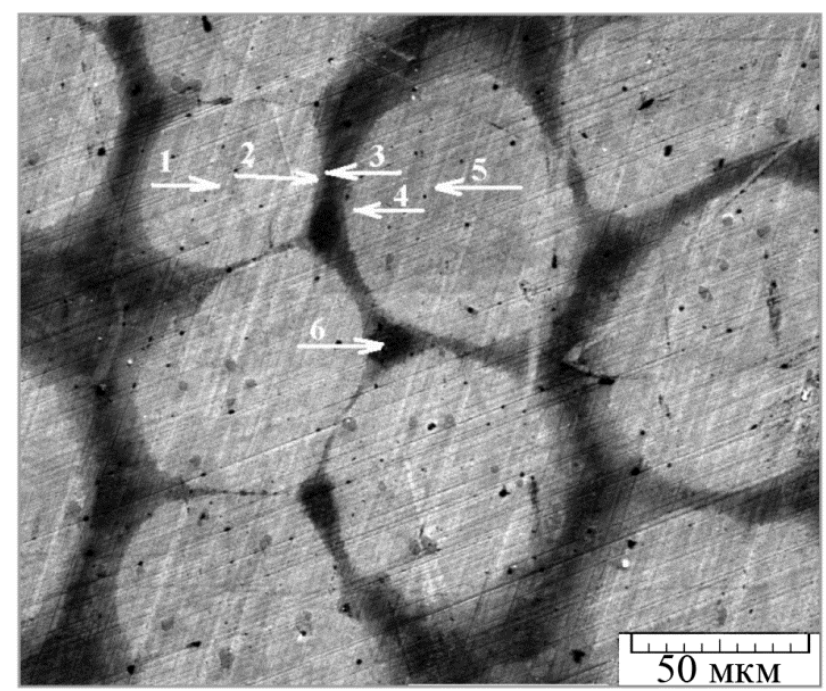

Рис. 1. Участки микроанализа

Таблица 4 - Результаты микрорентгеноспектрального анализа участков поверхности шлифа образца, вырезанного из трубной заготовки (участки отмечены на рис. 1)

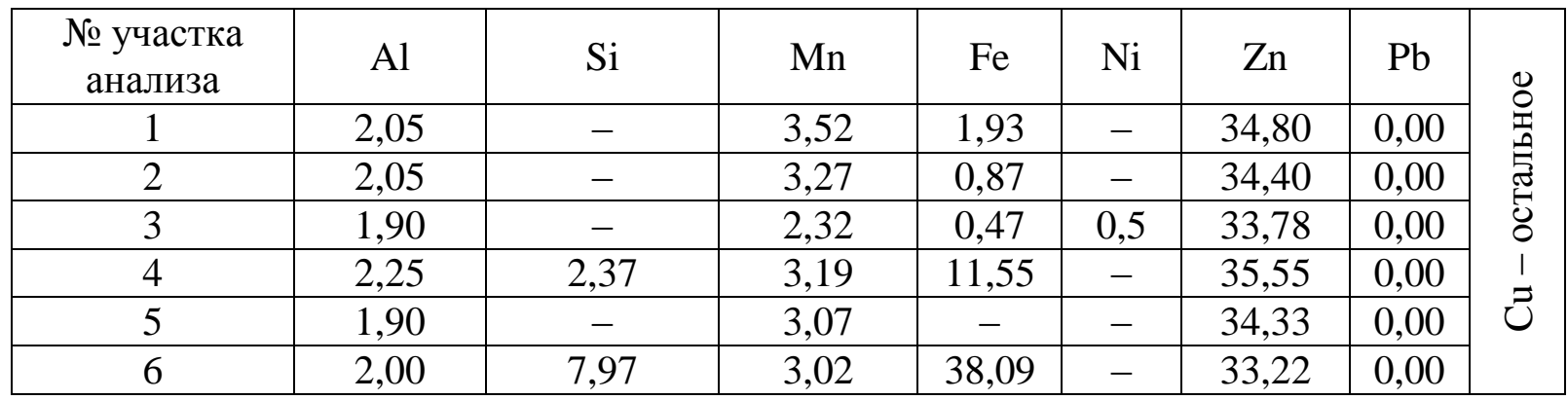




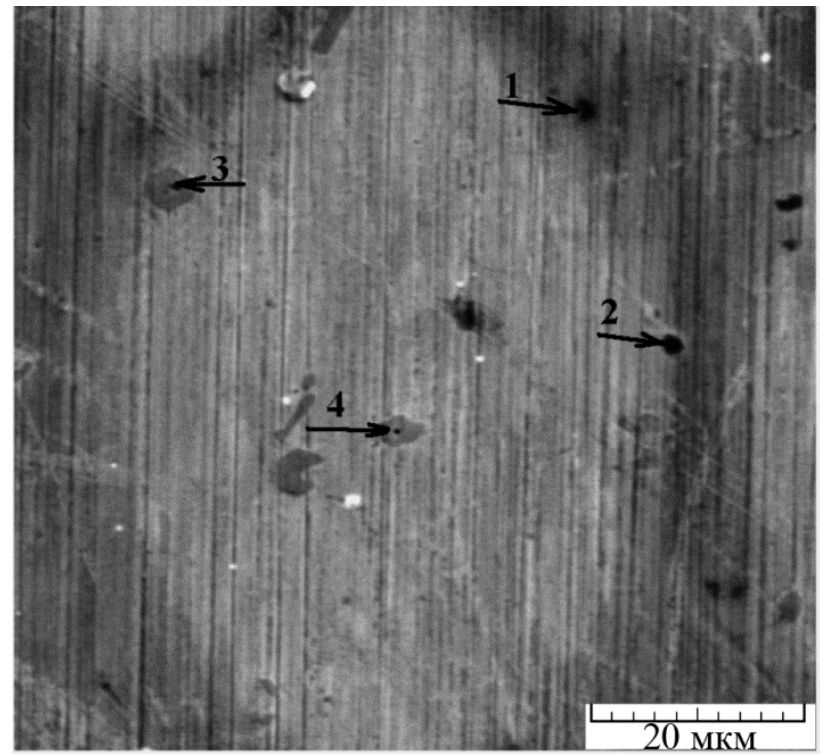

Рис. 2. Растровое изображение структуры латуни ЛМцАЖН во вторичных электронах с указанием участков микроанализа

Таблица 5 - Результаты локального анализа химического состава на участках, отмеченных на рис. 2

\begin{tabular}{|c|c|c|c|c|c|c|c|c|c|}
\hline $\begin{array}{c}\text { № участка } \\
\text { анализа }\end{array}$ & $\mathrm{Al}$ & $\mathrm{Si}$ & $\mathrm{Cr}$ & $\mathrm{Mn}$ & $\mathrm{Fe}$ & $\mathrm{Ni}$ & $\mathrm{Zn}$ & $\mathrm{Pb}$ & 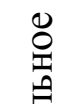 \\
\hline 1 & 0,67 & - & - & 1,02 & 1,93 & - & 8,52 & 45,33 & \\
\hline 2 & 0,71 & - & - & 1,41 & 0,87 & - & 14,16 & 31,80 & \\
\hline 3 & 1,29 & 9,37 & 0,34 & 4,38 & 11,55 & - & 15,82 & - & \\
\hline 4 & 1,44 & 7,97 & 1,04 & 10,66 & 38,09 & - & 8,79 & 7,30 & \\
\hline
\end{tabular}

Внешний вид кольцевой заготовки № 1 с образовавшейся после штамповки сквозной трещиной представлен на рис. 3. В кольце № 2 трещина образовалась после механического воздействия ножовкой при вырезке образца для исследований (рис. 4). Фрактографические исследования показали, что по макрогеометрии поверхности трещин колец № 1 и 2 являются неоднородными и характеризуются наличием двух зон, отличающихся по макрорельефу [13]. Одна - зона камневидного излома с грубозернистым строением и трещинами по границам зерен (участок А на рис. 5), характерная для хрупкого разрушения, вторая - зона волокнистого излома с матовой шероховатой поверхностью и признаками пластической деформации в виде утяжек (участок Б на рис. 5), занимающая большую часть поверхности разрушения. 


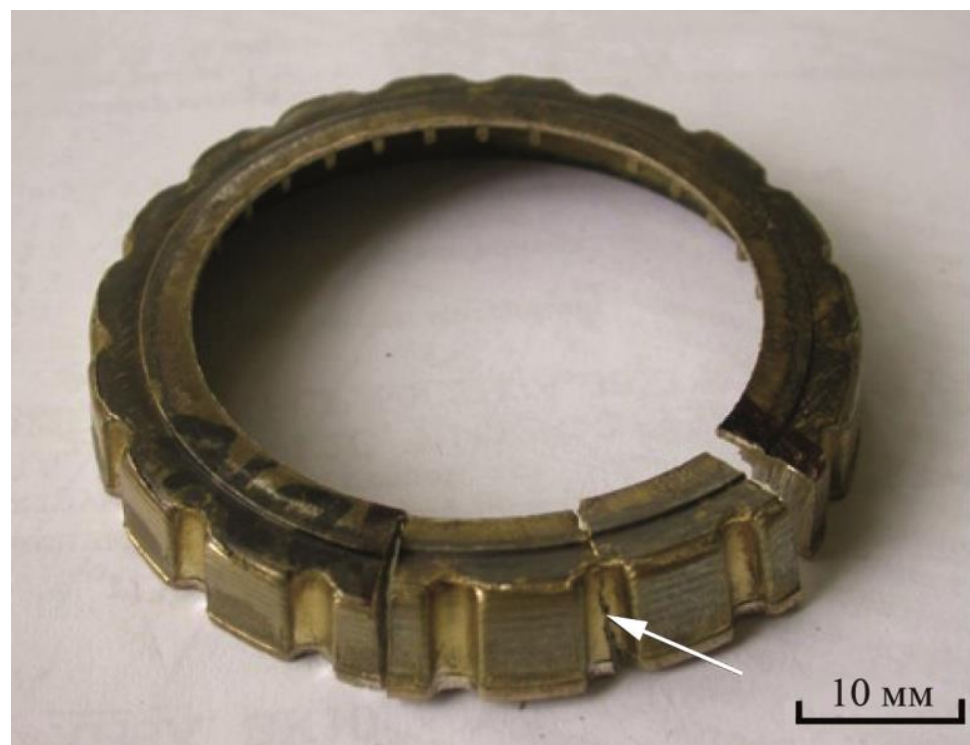

Рис. 3. Общий вид заготовки № 1, трещина на всю высоту кольца (показана стрелкой)

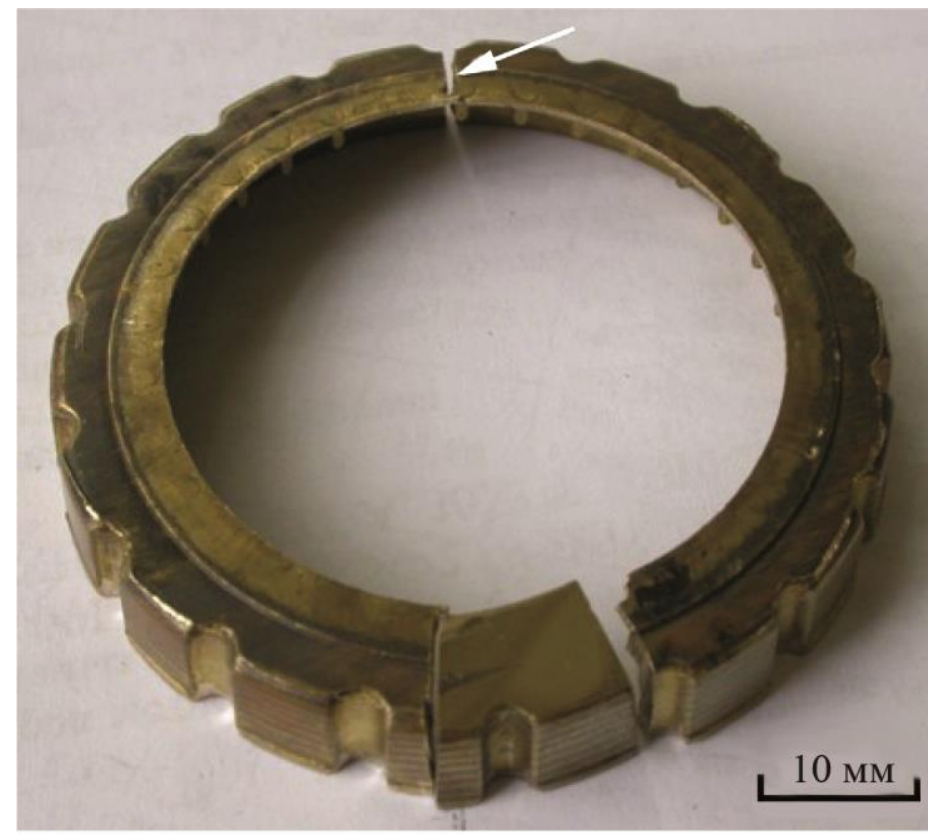

Рис. 4. Общий вид кольцевой заготовки № 2 с трещиной (показана стрелкой), образовавшейся на противоположной от места реза ножовкой стороне кольца 




Рис. 5. Рельеф поверхности раскрытой трещины на кольцевой заготовке № 1: А - зона камневидного излома; Б - зона волокнистого излома

На микроуровне в зоне А выявлены фасетки квазискола (рис. 6 a) и зернограничные трещины, вдоль которых наблюдали ручьистый излом (рис. 6 б). В зоне вязкого излома Б наблюдали волокнисто-полосчатое строение (рис. 7) с характерным ямочным изломом. В исследованной латуни количество и размер частиц силицидов невелики и ограничены малым содержанием кремния и железа, в исследованных кольцах их содержание не превышает 2,5 об. \%. При фрактографических исследованиях каких либо трещин или отслоений ни внутри частиц силицидов, ни по межфазным границам на поверхности разрушения не обнаружено (рис. 8 a), трещины наблюдали только по границам $\beta^{\prime}$-зерен.

Неметаллические включения, обнаруженные на поверхности разрушения образца № 1 нельзя считать причиной растрескивания кольцевой заготовки, так как трещин вблизи них нет: множественные углеродсодержащие включения сосредоточены в теле зерна вблизи поверхности (рис. 8 б), а трещины развиваются по границам зерен, не только вблизи поверхности, но и по всему объему заготовки.

Для заготовок № 1 и 2 характерно значительное увеличение размеров $\beta^{\prime}$-зерен (до 280 мкм вблизи наружной поверхности) (рис. 9). Условием аномального роста отдельных зерен (развития вторичной рекристаллизации) является энергетические преимущества отдельных зерен по отношению к другим, например, вследствие неравномерно распределенных остаточных напряжений трубных заготовок, что и приводит к их аномальному росту при нагреве под штамповку $[14,15]$. Для кольцевых заготовок после горячей штамповки характерно полное отсутствие $\alpha$-фазы, которая не успевает выделиться из $\beta$-фазы при быстром охлаждении, что, как было установлено ранее [6-8], облегчает растрескивание по границам зерен под действием сформировавшихся при штамповке внутренних остаточных напряжений. 


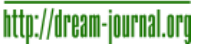


Рис. 6. Фасетки межзеренного разрушения $(a)$ и трещины по границам зерен $(\sigma)$ на участке А камневидного излома, заготовка № 1

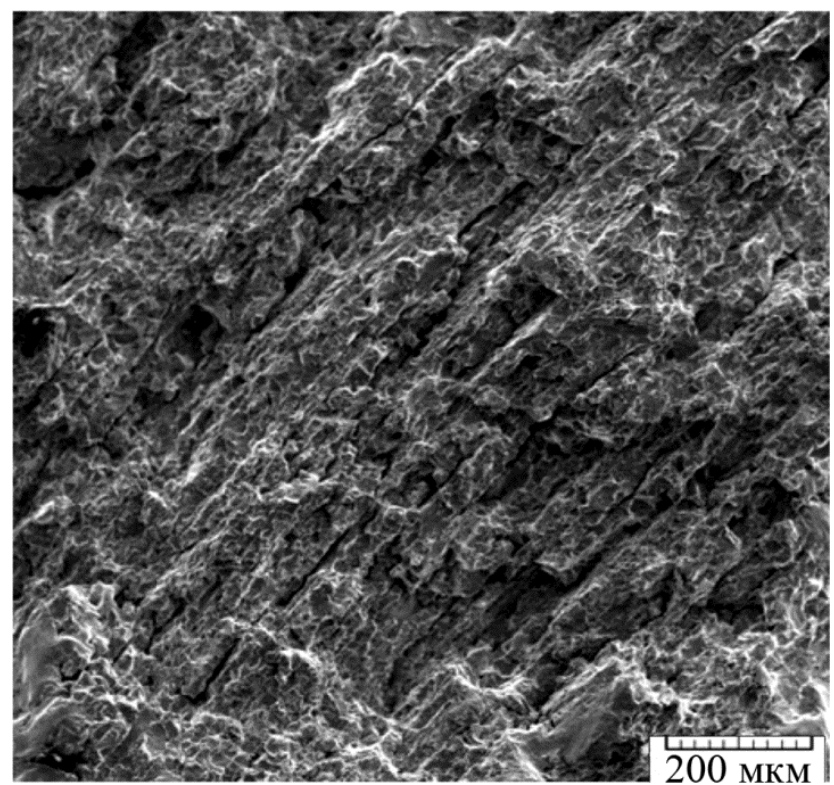

Рис. 7. Участок волокнистого (вязкого) излома с множественными трещинами, кольцо № 1, участок Б

Pugacheva N. B. et. al / Reasons for cracking of die-forged CuZn34Mn3Al2FeNi brass blanks 




$a$



б

Рис. 8. Рельеф поверхности трещины кольца № 1: $a$ - с частицами силицидов; $\sigma$ - с углеродосодержащими частицами и оксидом $\mathrm{SiO}_{2}$ (указаны стрелками)

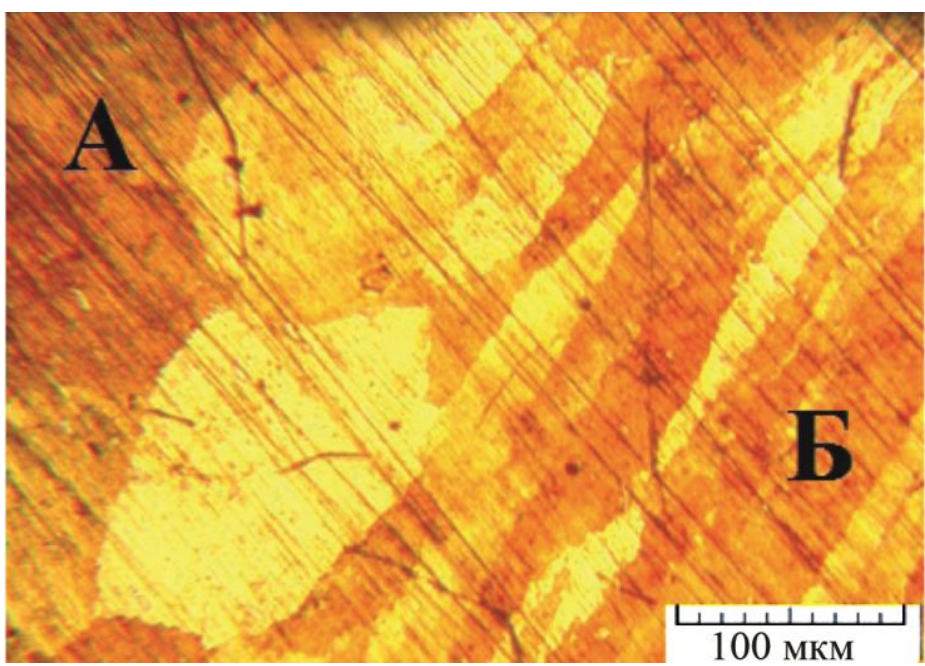

$a$

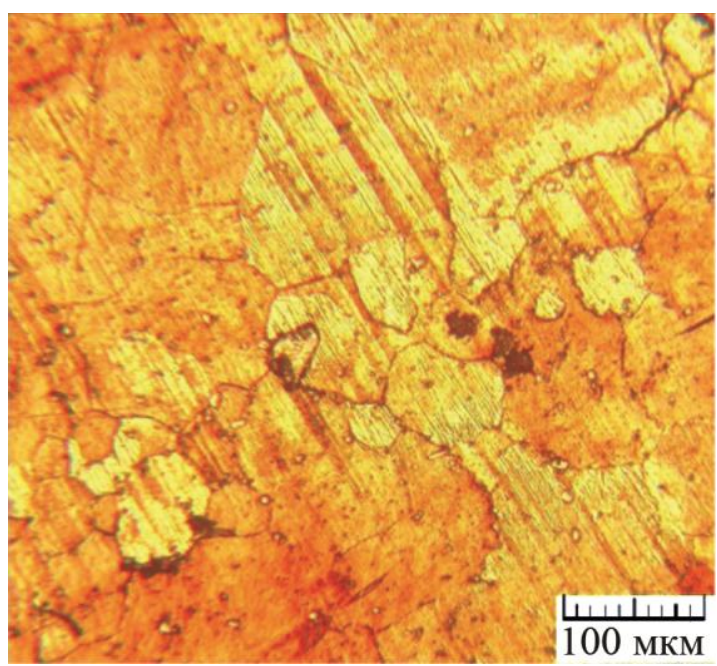

$\sigma$

Рис. 9. Микроструктура латуни ЛМцАЖН в кольцевой заготовке № 2: $a$ - сечение вдоль трещины; $\sigma$ - сечение поперек трещины в зоне А (рис. 5 )

В отличие от колец № 1 и 2 , в материале колец № 3-5 трещины не были обнаружены после горячей штамповки (табл. 2), поэтому для исследований они были сломаны путем изгиба, полученные изломы соответствовали вязкому разрушению (рис. 10). На изломе кольца № 3 отмечено 8 фасеток внутризеренного квазискола с гладкими или слегка волнистыми поверхностями (на рис. 10 отмечены стрелками), остальная поверхность имела признаки пластической деформации - ямочный излом. Структурное состояние сплава кольцевой заготовки № 3 не отличалось от № 1 и 2. Твердость материала кольцевых заготовок составила: для № $1-83 \mathrm{HRB}$, № 2 - $87 \mathrm{HRB}$, № 3 - 78 HRB. Такое разночтение по твердости свидетельствует о неоднородности температурных полей при нагреве под штамповку в производственных условиях, а также об отличиях скоростей охлаждения после штамповки. 


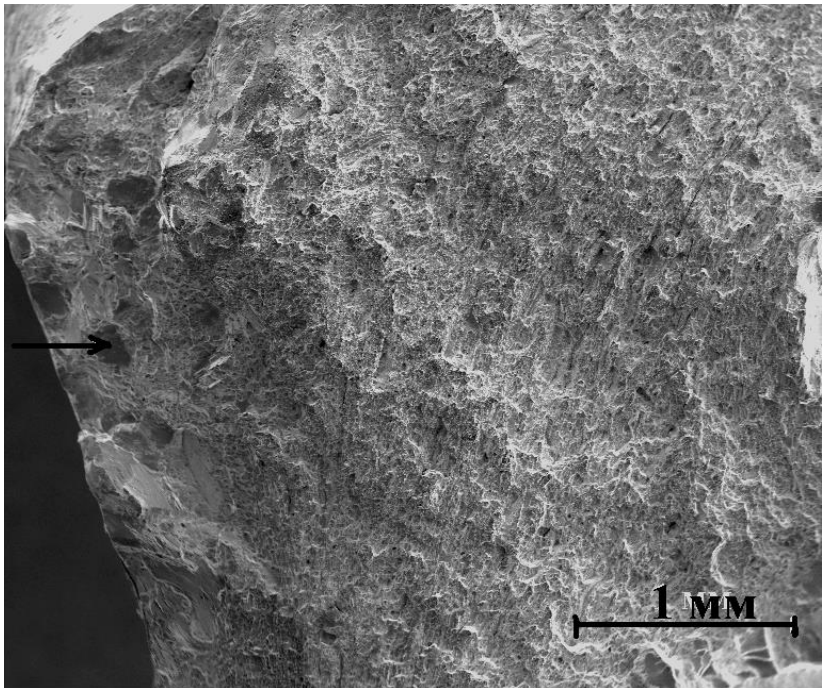

$a$

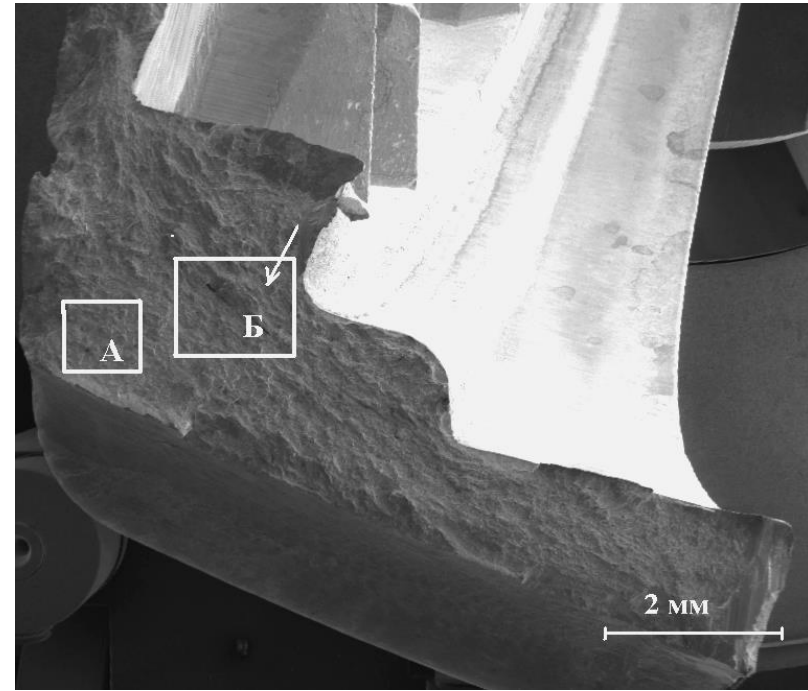

$\sigma$

Рис. 10. Рельеф поверхности разрушения кольцевой заготовки № 3 (a) и № 4 (б)

Таким образом, результаты фрактографических и металлографических исследований показали, что целесообразно снизить температуру нагрева кольцевых заготовок перед штамповкой. Это позволит исключить, во-первых, чрезмерный рост $\beta$-зерен, во-вторых, возможность появления зернограничных легкоплавких эвтектик, ослабляющих границы $\beta$ '-зерен. Главными требованиями при выборе температуры нагрева колец под штамповку являются максимальная заполняемость формы, снижение уровня остаточных напряжений после штамповки, прочность межзеренных границ. Предпочтительно выбрать температуру нагрева не выше температуры прессования трубных заготовок $\left(700^{\circ} \mathrm{C}\right)$.

При исследовании поверхностей изломов колец № 4 и 5, для которых температура нагрева под штамповку была снижена до $700{ }^{\circ} \mathrm{C}$ (табл. 2), обнаружено отсутствие участков хрупкого разрушения, подобных участку А на рис. 5. По всей поверхности разрушения излом соответствует вязкому разрушению (рис. 10 б). На микроуровне на участках поверхности волокнисто-полосчатого излома выявлено значительно меньше микротрещин по сравнению с заготовками № 1-3. Размер $\beta$ '-зерен материала заготовок № 4 и 5 на превышал 150 мкм, количество силицидов, как и в кольцевых заготовках № 1-3, составило не более 2,5 об. \%, $\beta$-фаза полностью отсутствовала. Значения твердости колец № 4 и 5 составили 80-82 HRB, что удовлетворяет предъявляемым требованиям к материалу блокирующих колец синхронизатора коробки перемены передач из латуни ЛМцАЖН $-\mathrm{HRB} \geq 80$.

При микрорентгеноспектральном анализе материала исследованных колец обнаружено, что по химическому составу границы $\beta^{\prime}$-зерен практически не отличаются от центральной части зерна (рис. 11, табл. 6). На границах $\beta^{\prime}$-зерен не наблюдается каких-либо примесей, частиц или следов оплавления или окисления. Частицы силицидов $(\mathrm{Fe}, \mathrm{Mn})_{5} \mathrm{Si}_{3}$ располагаются в теле $\beta^{\prime}$-зерен, рядом с ними, как правило, расположены частицы свинца.

Исследование поверхности продольного реза кольца № 2 методом обратнорассеянных электронов показало, что выделенные на рис. 5 зоны А и Б существенно отличаются ориентировкой зерен. В процессе горячей штамповки колец создается неравномерное напряженно-деформированное состояние по профилю заготовок. Максимальная деформация характерна для участка Б, а минимальная - для участка А. По ранее проведенным исследованиям [16] определено, что в зоне максимальной деформации действуют сжимающие напряжения, а в зоне с минимальной - растягивающие. Для латуни кольца на участке А характерна разориентировка крупных зерен (рис. 12), причем 
на границе крупных $\beta^{\prime}-$-ерен явно просматриваются новые субзерна, отличающиеся ориентировкой от остальных (рис. 13).



Рис. 11. Участки локального микрорентгеноспектрального анализа материала кольца № 4 (результаты приведены в табл. 6)

Зона Б, наоборот, характеризуется наличием явно выраженной текстуры (рис. 14). Максимальная полюсная плотность зафиксирована для кристаллов (001) в направлении X и (101) в направлении $\mathrm{Z}$ для участка A (рис. 15 б) и для кристаллов (001) в направлении X на участке Б (рис. 15 в). На прямых полюсных фигурах для области А видны в основном размытые хаотично расположенные пики интенсивности и лишь один острый пик большой интенсивности для плоскостей $\{100\}$ в направлении Х (рис. 15 a). На обратных полюсных фигурах для области А зафиксирован дополнительный пик повышенной интенсивности (101) в направлении $\mathrm{Z}$ (рис. 15 б), что свидетельствует о протекании процессов динамической полигонизации в области А $[17,18]$.

Таблица 6 - Результаты локального микрорентгеноспектрального анализа материала кольца № 4 (участки отмечены на рис. 11), масс. \%

\begin{tabular}{|c|c|c|c|c|c|c|c|c|c|}
\hline $\begin{array}{c}\text { № } \\
\text { участка }\end{array}$ & $\mathrm{Mg}$ & $\mathrm{Al}$ & $\mathrm{S}$ & $\mathrm{Mn}$ & $\mathrm{Ni}$ & $\mathrm{Cu}$ & $\mathrm{Zn}$ & $\mathrm{Se}$ & Примечание \\
\hline 1 & - & 2,0 & - & 2,8 & 0,5 & \multirow{5}{*}{ 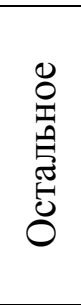 } & 35,6 & - & \multirow{3}{*}{ 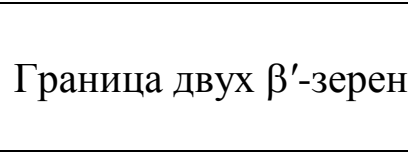 } \\
\hline 2 & - & 2,1 & - & 2,7 & 0,4 & & 36,3 & - & \\
\hline 3 & - & 2,0 & - & 2,9 & 0,5 & & 35,90 & - & \\
\hline 4 & 0,5 & 0,9 & 13,6 & 22,7 & - & & 15,28 & 1,86 & $\begin{array}{c}\text { Неметаллическое } \\
\text { включение }\end{array}$ \\
\hline 5 & - & 2,1 & - & 2,8 & 0,4 & & 36,16 & - & Тело $\beta^{\prime}$-зерна \\
\hline
\end{tabular}

В зоне Б зафиксирован поворот текстуры для плоскостей $\{100\}$, а также появились дополнительные хаотически расположенные максимумы с большей интенсивностью (рис. 15 в). При рассмотрении карт ориентировок обнаружено, что в зоне Б внутри $\beta^{\prime}$-зерен присутствуют разориентированные блоки и новые дисперсные зерна (рис. 14), что является признаком динамической рекристаллизации $[17,18]$. 


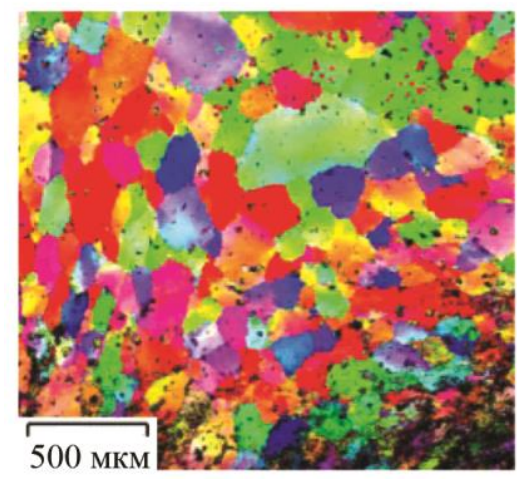

$a$


$\sigma$
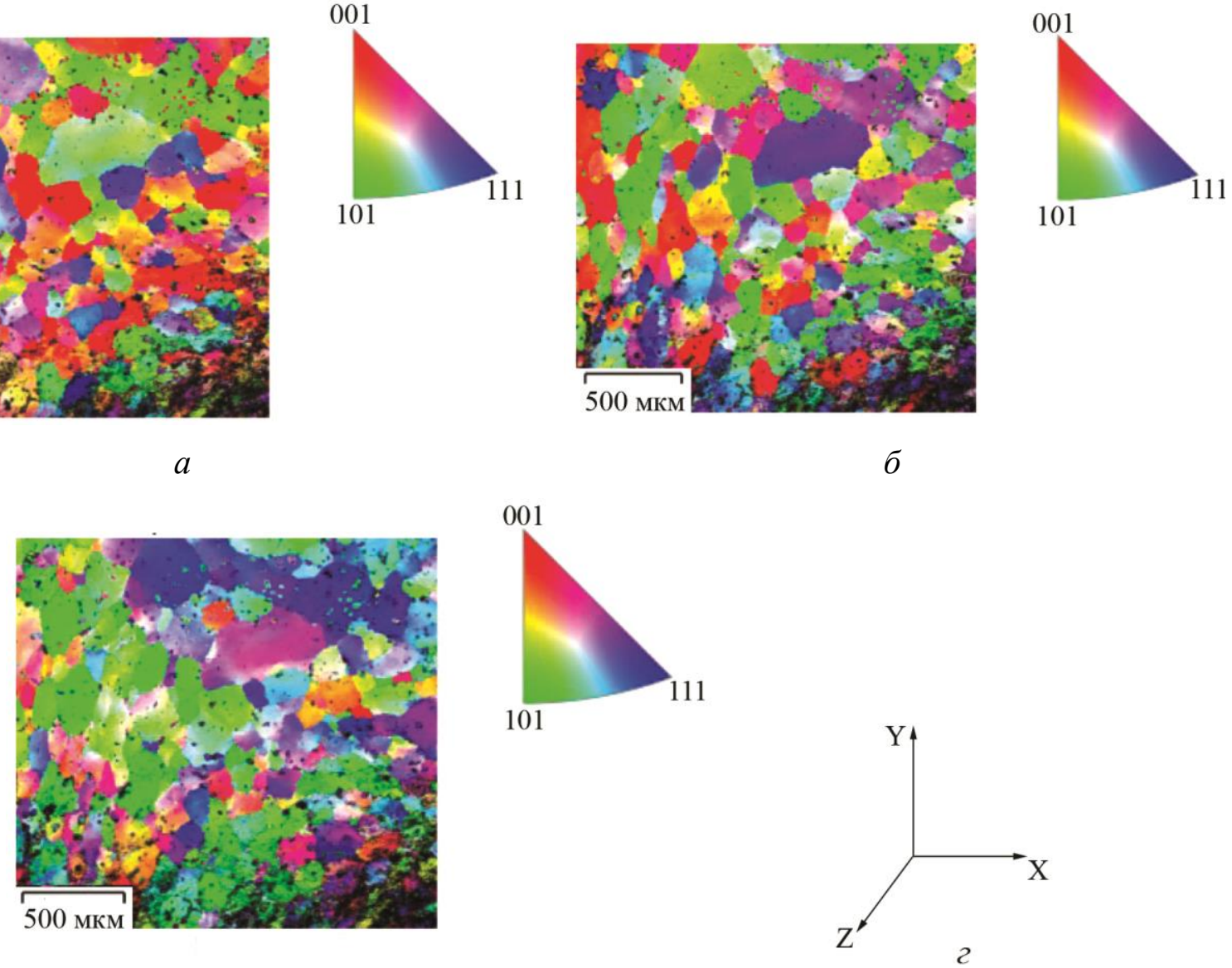

B

Рис. 12. Карты ориентировок $\beta^{\prime}$-зерен участка А кольца № 2 и легенды к ним в пространствах обратных полюсных фигур: $a$ - вдоль направления $\mathrm{X}$; $\sigma$ - вдоль направления Y; в - вдоль направления Z; 2 - расположение осей

Для анализа степени протекания рекристаллизационных процессов при горячей штамповке были построены карты рекристаллизации (рис. 16). Строятся они по следующему алгоритму: сначала проводится реконструкция зерен, затем программным путем измеряются средние разориентировки в пределах зерна $[17,18]$. Если средний угол разориентировки в зерне превышает $2^{\circ}$, то зерно идентифицируется как деформированное. Некоторые зерна состоят из субзерен. В этом случае, если внутренняя разориентировка в субзерне не превышает $2^{\circ}$, а от субзерна к субзерну превышает, то зерно идентифицируется как субструктурное (полигонизованное). Если же средний угол разориентировки не превышает $2^{\circ}$, то зерно рекристаллизованное. В материале участка Б практически полностью прошли рекристаллизационные процессы, образовалась мелкозернистая структура (рис. 16 2), поэтому разрушение в этой зоне носит вязкий характер. 




$a$

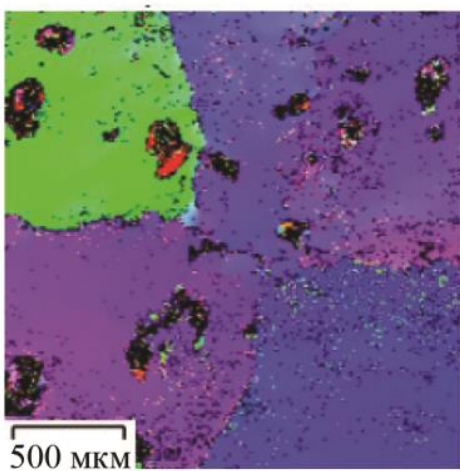

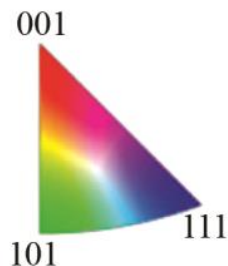

001
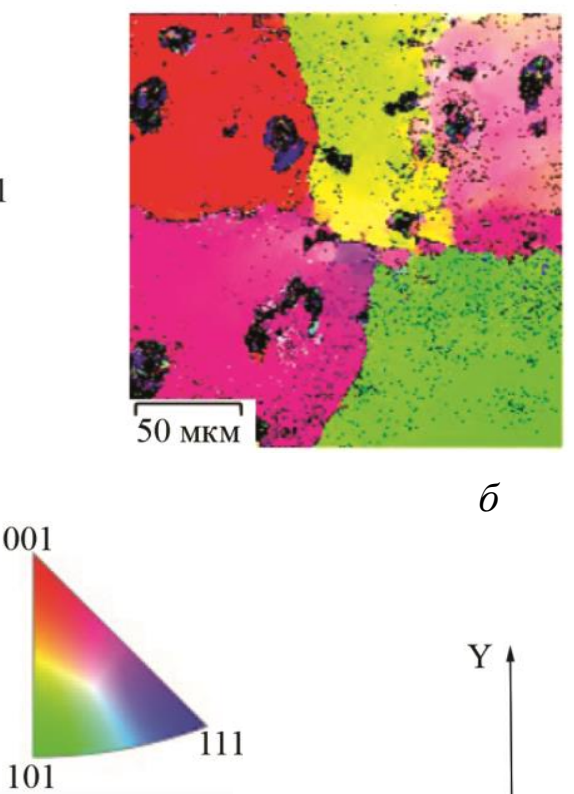

$\sigma$
001

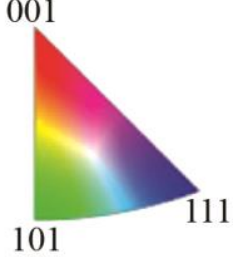

B

Рис. 13. Карты ориентировок $\beta^{\prime}$-зерен участка А кольца № 2 и легенды к ним в пространствах обратных полюсных фигур: $a$ - вдоль направления X; $\sigma$ - вдоль направления $\mathrm{Y}$; в - вдоль направления Z; 2 - расположение осей

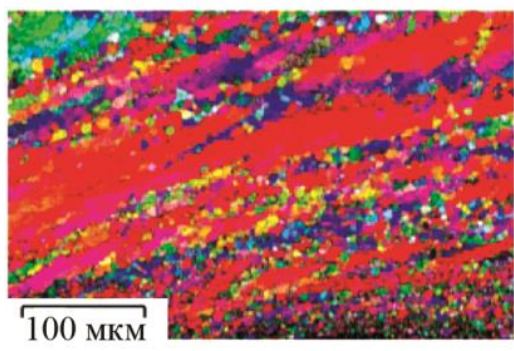

$a$

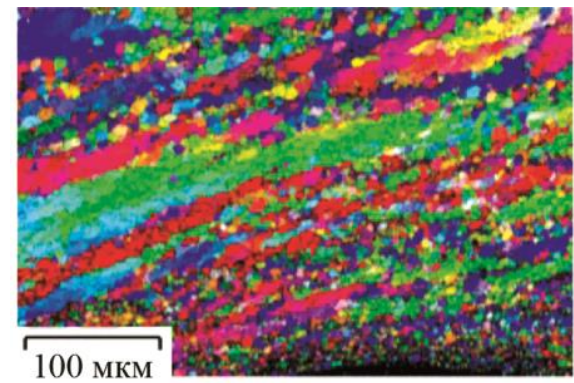

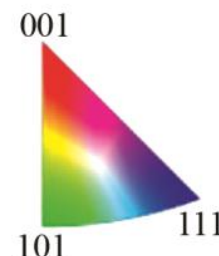

101

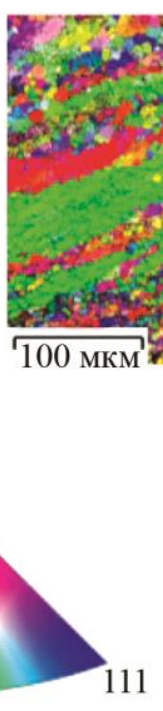

101

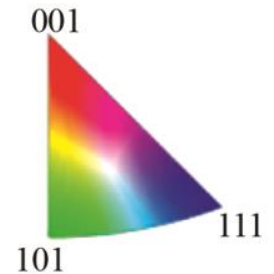

B



Рис. 14. Карты ориентировок $\beta$ '-зерен участка Б кольца № 2 и легенды к ним в пространствах обратных полюсных фигур: $a$ - вдоль направления X; $\sigma$ - вдоль направления $\mathrm{Y} ;$ в - вдоль направления Z; г - расположение осей 

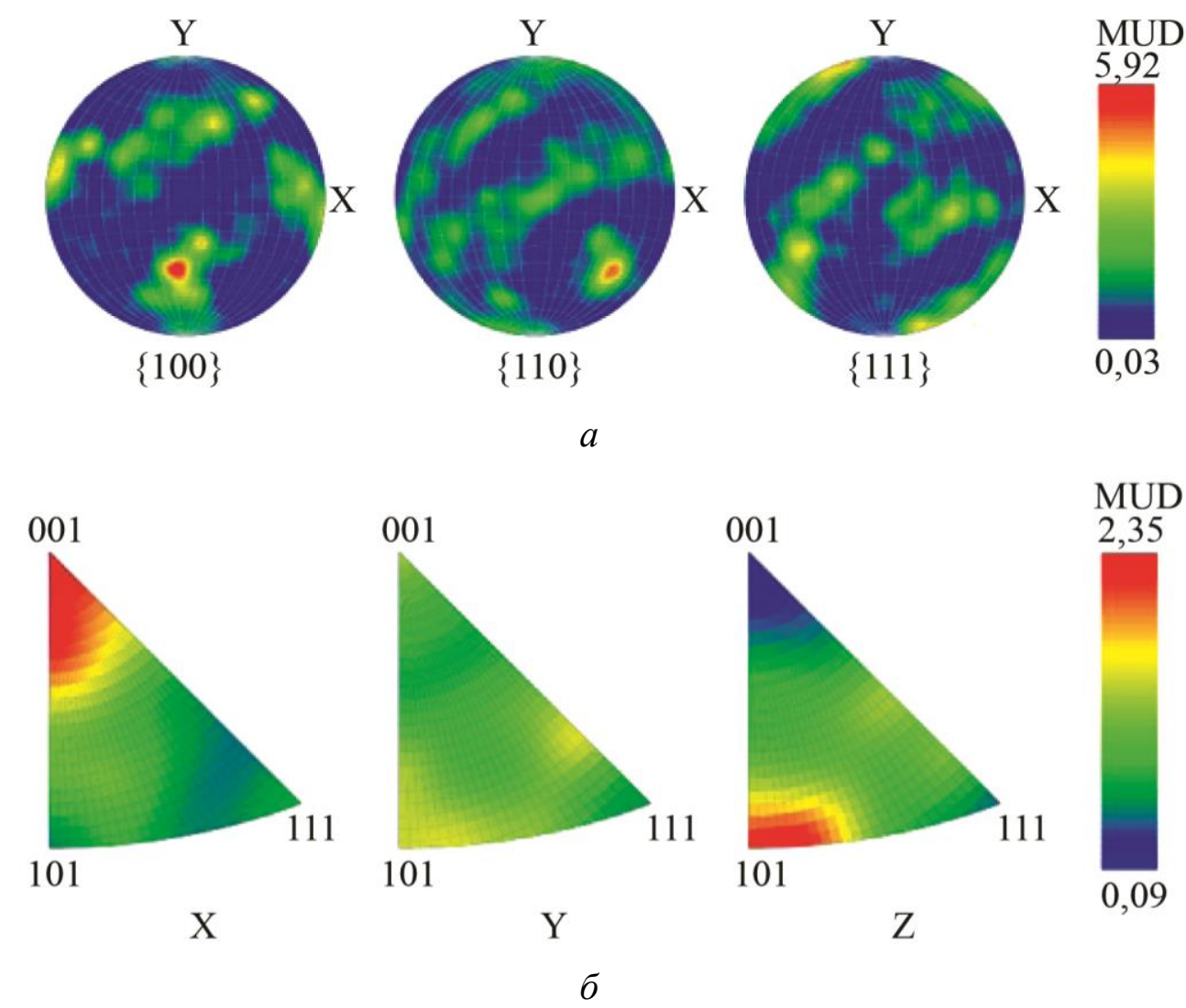

MUD



101
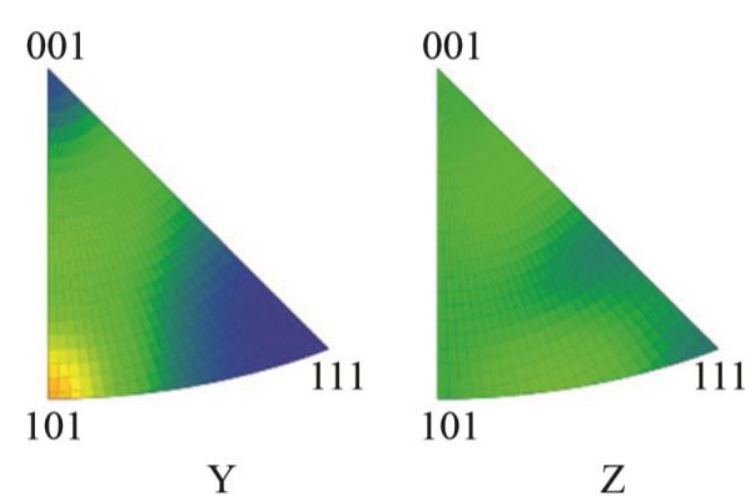

MUD

3,45
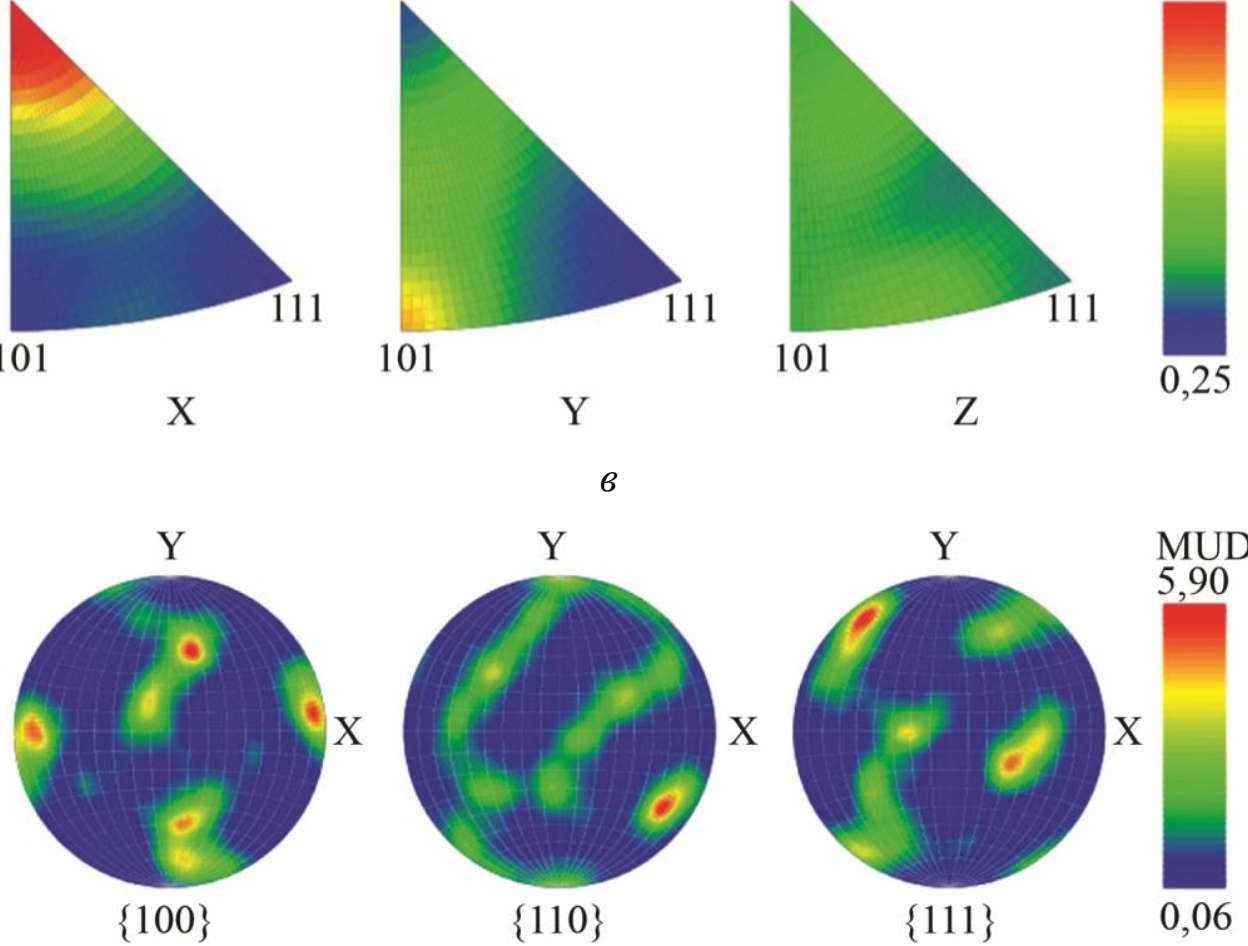

$\{110\}$

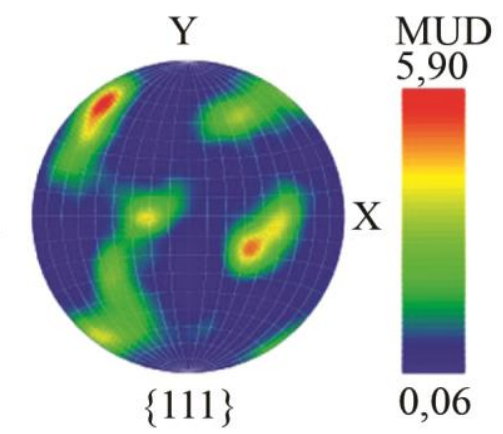

Рис. 15. Прямые $(a, 2)$ и обратные $(\sigma, \varepsilon)$ полюсные фигуры участков $\mathrm{A}(a$, б) и Б $(6,2)$ кольца № 2 
ittp.///ream-journal.or"]

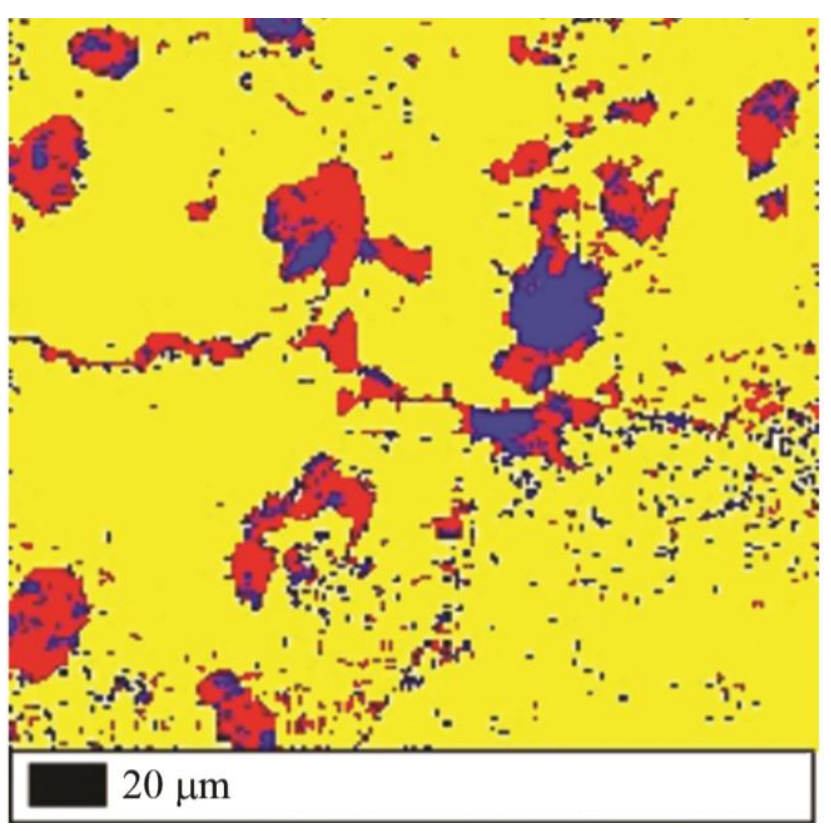

$a$



B



$\sigma$

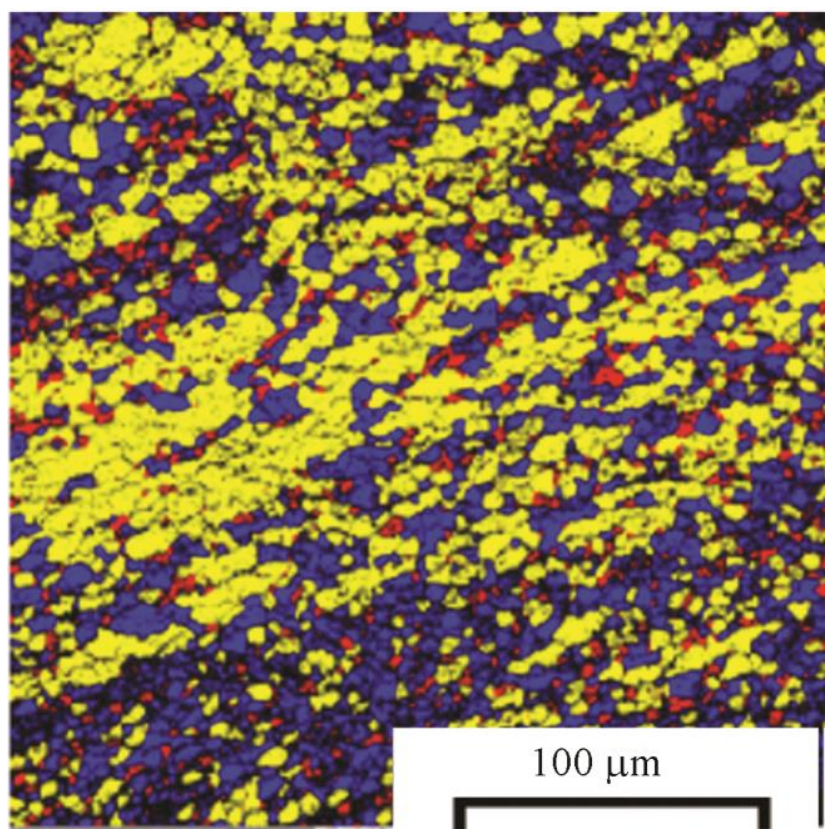

2

Рис. 16. Карты рекристаллизации латуни на участках А $(a)$ и Б (2) кольца № 2 (синий ивет - полностью рекристаллизованный материал, желтый - субструктурный материал, красный - деформированное зерно с повышенной плотностью дислокаций);

$\sigma$ - карта напряжений для участка А (синий - минимальные напряжения, зеленый - максимальные); в - карта контуров

В материале участка А зафиксированы отдельные мелкие деформированные зерна и субзерна вблизи границ крупного $\beta^{\prime}-$ зерна (рис. $16 a$ и в). Известно $[14,15]$, что при динамической рекристаллизации, вновь образовавшиеся зерна характеризуются повышенной плотностью дислокаций, т. е. являются нагартованными. Это подтверждают полученные при EBSD-анализе карты рекристаллизации: практически все крупные зерна имеют равноосную структуру, тогда как по границам зерен зафиксированы мелкие зерна (или субзерна), которые отнесены программой HKL Channel 5 к пластически деформированным.

Pugacheva N. B. et. al / Reasons for cracking of die-forged CuZn34Mn3Al2FeNi brass blanks 
Максимальные значения внутренних напряжений зафиксированы по границам $\beta^{\prime}$-зерен (рис. 16 б). Карта напряжений является качественным показателем степени разориентировки кристаллов, и по сути области с максимальными напряжениями соответствуют областям с большей плотностью дислокаций $[17,18]$. Выполненные измерения значений микротвердости по сечению крупных $\beta^{\prime}$-зерен показали, что вблизи границ твердость составила около $300 \mathrm{HV}$ 0,02, тогда как в теле зерна - всего $170 \mathrm{HV}$ 0,02. Скорее всего именно с упрочнением приграничных участков $\beta^{\prime}$-зерен на участке А при динамической рекристаллизации и связано резкое охрупчивание границ, проявившееся в формировании ручьистого узора на поверхности образовавшейся трещины в кольцевой заготовке (рис. 6 б).

Известно, что динамическая рекристаллизация происходит при достижении критической степени деформации [14]. В процессе горячей штамповки колец наблюдается неравномерная деформация, а также неравномерное распределение напряжений по профилю заготовок [16]. Максимальная деформация характерна для участка Б, а минимальная - для участка А. Для участка А критическая степень деформации не достигается, поэтому там происходит только динамическая полигонизация.

Никель и железо введены в латунь ЛМцАЖН с целью предотвращения чрезмерного роста зерен при нагреве под горячую деформацию. Очевидно, что при температуре $80{ }^{\circ} \mathrm{C}$ влияние этих элементов уже не проявляется в достаточной мере. Кроме того, известно, что чем выше температура горячей деформации, т.е. чем быстрее протекают диффузионные процессы, тем быстрее происходит динамическая рекристаллизация [14, 15]. При температуре нагрева под штамповку колец $700{ }^{\circ} \mathrm{C}$ размер $\beta^{\prime}$-зерен на участке А увеличился в меньшей степени по сравнению с температурой нагрева $780{ }^{\circ} \mathrm{C}$, кроме того, не произошло упрочнения границ зерен, связанного с началом динамической рекристаллизации. Очевидно при нагреве до $700{ }^{\circ} \mathrm{C}$ еще проявляется благоприятное действие легирования латуни никелем и железом, поэтому формирующиеся после горячей штамповки остаточные напряжения не приводят к появлению трещин в кольцевых заготовках.

\section{Таблица 7 - Результаты исследований по снижению температуры нагрева перед операцией штамповки}

\begin{tabular}{|l|c|c|}
\hline \multicolumn{1}{|c|}{ Параметры выборки } & $\begin{array}{c}\text { Штатный режим } \\
\text { нагрева заготовок }- \\
780{ }^{\circ} \mathrm{C}\end{array}$ & $\begin{array}{c}\text { Опытный режим } \\
\text { нагрева заготовок }- \\
700{ }^{\circ} \mathrm{C}\end{array}$ \\
\hline Отштамповано колец, шт & 100 & 100 \\
\hline Выявлено брака по трещинам, шт & 21 & 31 \\
\hline $\begin{array}{l}\text { После отбора образцов допущено к кон- } \\
\text { тролю по незаполняемости штампа, шт }\end{array}$ & 80 & 11 \\
\hline $\begin{array}{l}\text { Забраковано колец по незаполняемости } \\
\text { штампа, шт }\end{array}$ & 13 & 3 \\
\hline
\end{tabular}

Выполненные на ОАО «АВТОВАЗ» испытания показали, что из партии в 100 колец, отштампованных по штатному и опытному режимам, в брак по трещинам отошло $21 \%$ заготовок (табл. 7) при нагреве кольцевых заготовок перед штамповкой до $780{ }^{\circ} \mathrm{C}$ и всего $3 \%$ заготовок при нагреве их перед штамповкой до $700^{\circ} \mathrm{C}$. Таким образом, полученные данные еще раз подтверждают тот факт, что температура нагрева заготовок перед штамповкой по технологии ОАО «АВТОВАЗ» является завышенной, что и приводит к их растрескиванию под действием остаточных напряжений. 


\section{Выводы}

1. Выполненные исследования показали, что в процессе горячей штамповки колец наблюдается неравномерная по сечению заготовки деформация. В области с минимальной степенью деформации происходит динамическая полигонизация, а в зоне с повышенным значением пластической деформации зафиксировано практически полное протекание динамической рекристаллизации с образованием мелкого, свободного от дислокаций $\beta^{\prime}-$-зерна.

2. Причинами растрескивания колец из латуни ЛМцАЖН являются формирующиеся при быстром охлаждении остаточные напряжения. Трещина зарождается и мгновенно растет в зоне действия растягивающих напряжений, имеющей крупнозернистую структуру. При температуре штамповки $780{ }^{\circ} \mathrm{C}$ зафиксировано упрочнение границ крупных $\beta$ '-зерен, что облегчает рост трещины.

3. Установлено, что границы $\beta^{\prime}$-зерен не содержат каких-либо вредных примесей и легкоплавких эвтектик наличие частиц силицидов или неметаллических включений.

4. Снижение температуры штамповки до $700{ }^{\circ} \mathrm{C}$ не приводит к чрезмерному росту $\beta^{\prime}$-зерен, упрочнению приграничных областей и появлению трещин в охлажденной заготовке, поэтому следует рекомендовать горячую штамповку колец при данной температуре.

\section{Благодарности}

Работа выполнена при частичной поддержке проекта № 15-10-1-22 Фундаментальных научных исследований Уральского отделения РАН.

\section{Литература}

1. Сучков Д. И. Медь и ее сплавы. - М. : Металлургия, 1967. - 248 с.

2. Туркин В. Д., Румянцев М. В. Структура и свойства цветных металлов и сплавов. М. : Металлургиздат, 1944. - 440 с.

3. Ефремов Б. Н. Латуни. От фазового строения к структуре и свойствам : монография. Москва : ИНФРА-М, 2014. - 312 с.

4. Елагин В. И., Колачев А. В., Ливанов В. А. Металловедение и термическая обработка цветных металлов и сплавов: монография. - 4-е изд., перераб. и доп. - М. : МИСИС, 2005. $432 \mathrm{c}$.

5. Красненьков В. И. Егоркин В. В. Синхронизаторы в ступенчатых трансмиссиях. М. : Машиностроение, 1967. - 195 с.

6. Пугачева Н. Б. Структура и свойства деформируемых легированных латуней. Екатеринбург : УрО РАН, 2012.

7. Tropotov A. V., Pugacheva N. B., Ryazantsev Yu. V., Zhukova L. M. A study of residual stresses in products made of hard alloy of brass // Metal Science and Heat Treatment. - 2006. Vol. 47, nos. 1-2. - P. 31-35. - DOI: 10.1007/s11041-006-0039-5

8. Латунные сплавы для колец синхронизаторов совершенствуются / М. Д. Копыл, А. В. Тропотов, И. В. Котляров // Автомобильная промышленность. - 1999. - № 10. C. 26-29.

9. Plastic deformation of a high-alloy brass / S. V. Smirnov, N. B. Pugacheva, A. N. Soloshenko, A. V. Tropotov // Physics of Metals and Metallography. - 2002. - Vol. 93, no. 6. P. 584-593.

10. Cai W., Liu H. F., Hu Q. Effect of Ni on characteristics and stracture of Cu-22,7Zn Brass As-cast // Advanced Materials Research. - 2012. - Vol. 581-582, no. 1. - P. 556-560.

11. РД 50-672-88. Расчеты и испытания на прочность. Классификация видов изломов металлов. Методические указания. - М. : Издательство стандартов, 1989. - 21 с.

12. Шимов Г. В., Ковин Д. С. Остаточные напряжения в медных и латунных трубах после волочения // Известия высших учебных заведений. Цветная металлургия. - 2015. Спецвыпуск. - C. 46-49. - DOI: 10.17073/0021-3438-2015-1s-46-49 
13. Исследование характера и причин разрушения заготовок из сплава $58 \mathrm{Cu}-34 \mathrm{Zn}-3 \mathrm{Mn}-2 \mathrm{Al}$ после горячей штамповки / Н. Б. Пугачева, Е. Б. Трушина, Н. П. Антенорова, А. С. Овчинников, А. В. Лебедь // Вопросы материаловедения. - 2014. - № 1 (77). - С. 56-64.

14. Горелик С. С., Добаткин С. В., Капуткина Л. М. Рекристаллизация металлов и сплавов. - М. : Изд-во МИСИС. - 2005. -432 с.

15. Физическое материаловедение : учебник для вузов / С. В. Грачев, В. Р. Бараз, В. П. Богатов, В. П. Швейкин - 2-е изд., перераб. и доп. - Екатеринбург : Изд-во УГТУУПИ, 2009. - $548 \mathrm{c.}$

16. Тропотов А. В., Смирнов С. В., Кузнецов В. Ю. Прогнозирование надежности процесса штамповки детали «кольцо блокирующее синхронизатора» для легковых автомобилей // Металлообработка. - 2004. - № 3 (21). - С. 19-21.

17. Electron Backscatter Diffraction in Materials Science / A. J. Schwartz, V. Kumar, B. L. Adams, D. P. Field. - Boston : Springer, 2000. - 395 p. - DOI 10.1007/978-0-387-88136-2

18. Возможности метода дифракции обратнорассеянных электронов для анализа структуры деформированных материалов / В. Н. Варюхин, Е. Г. Пашинская, А. В. Завдовеев, В. В. Бурховецкий. - Киев : Наукова думка, 2014. - 102 с. 